\title{
Protection of Bank's Wealth: How is Islamic Banks's Financial Performance Affected by Asset Quality and Operational Efficiency
}

\author{
Muhammad Ahmar Ali ${ }^{1, *}$, Mohd Sollehudin Shuib ${ }^{1}$, Alias Mat Nor ${ }^{2}$ \\ ${ }^{1}$ Islamic Business School, College of Business, Universiti Utara Malaysia, 06010 Sintok Kedah, Malaysia \\ ${ }^{2}$ Institute of Shariah Governance and Islamic Finance (ISGaIF), Islamic Business School, College of Business, Universiti Utara \\ Malaysia, 06010 Sintok Kedah, Malaysia
}

Received May 30, 2021; Revised July 13, 2021; Accepted August 22, 2021

\begin{abstract}
Cite This Paper in the following Citation Styles
(a): [1] Muhammad Ahmar Ali, Mohd Sollehudin Shuib, Alias Mat Nor, "Protection of Bank's Wealth: How is Islamic Banks's Financial Performance Affected by Asset Quality and Operational Efficiency, " Universal Journal of Accounting and Finance, Vol. 9, No. 4, pp. 745 - 756, 2021. DOI: 10.13189/ujaf.2021.090420.
\end{abstract}

(b): Muhammad Ahmar Ali, Mohd Sollehudin Shuib, Alias Mat Nor (2021). Protection of Bank's Wealth: How is Islamic Banks's Financial Performance Affected by Asset Quality and Operational Efficiency. Universal Journal of Accounting and Finance, 9(4), 745 - 756. DOI: 10.13189/ujaf.2021.090420.

Copyright $@ 2021$ by authors, all rights reserved. Authors agree that this article remains permanently open access under the terms of the Creative Commons Attribution License 4.0 International License

\begin{abstract}
Islamic banks are recognised as entities which support social objectives as well as economic development of the country. Financial performance of the global Islamic banking and finance has shown promising growth as equal to well-established conventional banks. The study aims to investigate the effect of asset quality and operational efficiency on the financial performance of Islamic banks in Malaysia. The study uses panel data analysis, whereby the annual reports of 16 Islamic banks in Malaysia are analysed over a ten-year period from 2010 to 2019. The independent variables of the study are asset quality and operational efficiency. The dependent variable of the study is financial performance proxied by Return on Asset (ROA) and Return on Equity (ROE). Multiple regression models consisting of random-effect model and fixed-effect model are employed to analyse the data of the study. The findings of the study show that both asset quality and operational efficiency of Islamic banks have a significant influence on the financial performance proxied by ROA and ROE. Hence, the findings of the study evince the importance of proper management practices in protecting the wealth, as well as the financial performance of the Islamic banks.
\end{abstract}

Keywords Asset Quality, Financial Performance, Islamic Banks, Operational Efficiency

\section{Introduction}

The Islamic banking and finance discipline is nearly four decades old and its substantial growth has become a part of global capital markets and international banking systems. Financial performance, in terms of asset size of Islamic banks, has been growing steadily across the globe [1]. In fact, the financial performance of Islamic banks has been reported to have increased twice as fast as its counterparts [2]. The increase in global Islamic banking assets was substantial, at around USD 1.77 trillion in 2019 (see Figure 1). Regionally, Gulf Cooperation Council (GCC) countries dominated with the largest Islamic banking assets, amounting to USD854 billion in 2019, followed by Middle East, South Asian, Southeast Asian and African countries (see Figure 2).

This substantial growth of global Islamic banking assets has led to the growth of the domestic market shares of Islamic banks in the world, including in Malaysia [3]. The Islamic banking industry in Malaysia has been acknowledged as one of the international Islamic financial markets ever since its financial performance began showing remarkable improvements year-by-year. To date, 
Malaysian Islamic banking and finance services are ranked in the third position of global Islamic banking assets, at approximately USD 195.6 billion (11.1\%), after Iran (28.6\%) and Saudi Arabia (24.9\%), while its domestic market share leapt to a high of $28.4 \%$ in 2019 [3].

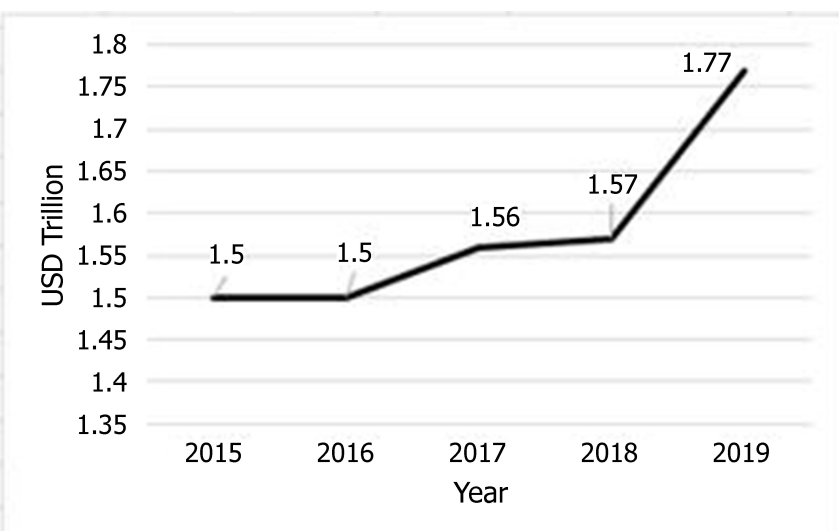

Source: Islamic Financial Services Industry Stability Reports by IFSB

Figure 1. Growth of global Islamic banking assets

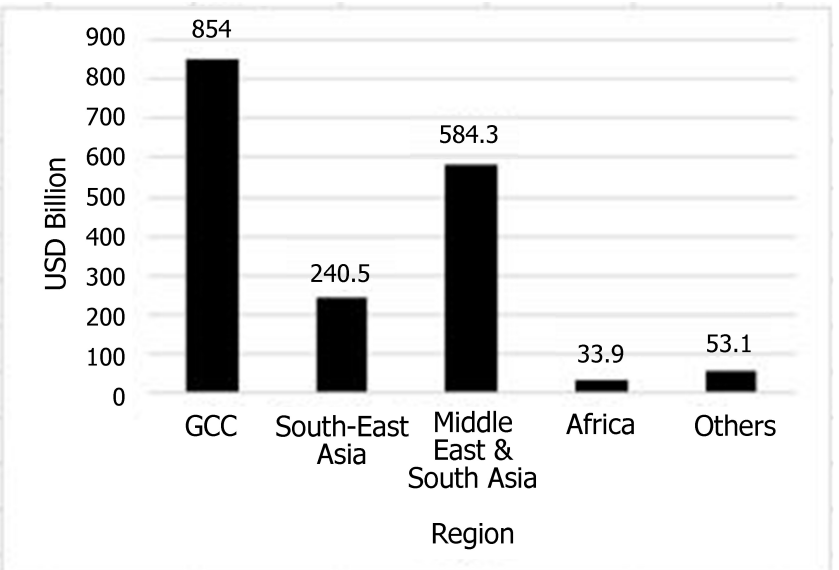

Source: Islamic Financial Services Industry Stability Reports by IFSB

Figure 2. Global Islamic banking assets by regions

Moreover, a study of [4] found that Islamic financial services in Malaysia have been undergoing significant growth stability and better asset quality when compared to its counterparts in neighbour countries. The study indicated that asset quality proxied by Non-Performing Financing (NPF) ratio on the assets of Malaysian Islamic banks is falling well below that of their conventional banks. The findings shown that good management risk has been undertaken by the Islamic banks banks as the excessive level of NPF is believed could indicate poor credit risk management practices and lead to the reduction of propensity for the banks to lend out more [5]. In addition, Malaysian Islamic banks also observed to be more efficient in controlling cost and generating profit than conventional banks [6]. The study of [6] indicated that the banks are implied that to be relatively more efficient at allocating resources compared to conventional banks in the country. Besides, according to [7], the operational efficiency is considered as one of the elements of measuring managerial quality of the Islamic banks under CAMELS rating system.

The growing wealth of the Islamic banks should be protected since it provides benefit to banks and it stakeholders itself. Management of the banks should take great concern on managing the stakeholder's wealth as Islam, for the sake of protecting wealth, forbid and placed punishments upon theft, deception, treason and consuming people's wealth unjustly, in addition to discouraging the squandering of money. As stated by [8] the objective of Islamic Financial Institutions (IFIs) including Islamic banks is to protect the wealth of stakeholders. The authors added that the IFIs are responsible to protect wealth of stakeholders of the banks from risk which can cause harm to it; and preventing wealth from damage through its harmful purposes.

Therefore, the study aims to investigate the effect of assets quality and operational efficiency as a part of aspects of protection of bank's wealth on financial performance of the Islamic banks in Malaysia

\section{Literature Review}

\subsection{Financial Performance}

The financial performance of firms, including financial and banking firms, is one of the indicators that signifies how efficient the firms are in managing the resources to achieve the goals and the interests of stakeholders [9]. Assessing the financial performance of an organisation is important for shareholders and stakeholders to make decisions, in particular, before undertaking any new investment activities. Shareholders and stakeholders must ensure that their organisation is financially secure and stable and able to generate profits. Particularly over the long-term, since it will lead to long-term growth, superior competitive advantage and sustainability [10].

Financial performance refers to financial capability, or the extent to which an organisation attains its economic goals. Basically, it is the responsibility of the management to improve financial performance because stakeholders, such as investors, creditors and employees, are very concerned with the company's performance as higher financial performance will bring about increased wealth for stakeholders. Financial performance can be measured by different indicators. Accounting-based measurements are commonly used to measure financial performance of organisations. Examples of accounting-based financial performance measurements are liquidity ratio, profitability ratio, leverage ratio and turnover ratio. Accounting-based measurements help the management as well as external stakeholders to analyse the financial condition of the organisation. According to [11] profitability ratio is a 
widely used to assess bank's performance and sustainable growth. Most prior studies that have examined financial performance in the Islamic banking sector, have measured financial performance by using financial accounting-based measurements, for example, net profit, net profit margin, return on assets (ROA) and return on equity (ROE), as found in the studies of $[12,13,14,15,16,17,18,19,20]$.

The financial performance of Islamic banks is believed to be affected by internal and external drivers, similar to conventional banks. Numerous empirical studies have proven that banks' specific characteristics and economic forces, for example, equity financing, liquidity and capital adequacy [21], operational cost [22,23], bank size and equity financing [21,24], and Gross Domestic Product (GDP) and inflation [25] have a significant influence on the financial performance of the banks.

In addition, Islamic banks have been proven to be more resilient to financial shocks during a financial crisis [26]; and their financial performance can lead to greater economic growth in the long-run [27]. Most of the prior empirical studies in Islamic banks have analysed the financial data available in Bankscope database, central bank databases as well as their respective annual reports in many countries, such as in Indonesia [28]; Pakistan [7,29]; Malaysia [30,31,32]; and the Middle East and North African (MENA) countries [33,34], have proven that financial performance of Islamic banks is characterised by different financial performance indicators, which lead to their having unique advantages over conventional banks. It has also been reported that the profitability of the global Islamic banking sector in terms of ROE in $2018(16.3 \%)$ was greater than that recorded by conventional banks over the same period in both the United States (US) and the European Union (EU) countries, at $11.9 \%$ and $7.2 \%$, respectively [35]. In addition, it has recently been reported that the profitability of the Islamic banks in Malaysia and the GCC region, in terms of ROA and ROE in 2019, was higher compared to the conventional banks [3]. The differences between performance of Islamic and conventional banks might be caused by different characteristics that are possessed by the Islamic banks. A study of [36] highlighted some of the unique and exclusive characteristics of Islamic banks which differentiates them from other financial institutions, including the promoting of justice and fairness for the public and the way they run their business in terms of operations and objectives compared to conventional banks.

However, a study of [10] argued that accounting-based measurements reflect only the historical performance of the business. The authors stated that assessing performance using historical accounting measures alone may not express the performance of the business. In this regard, long-term financial performance measurements, such as market value, can reflect the future development potential of an organisation [37].

\subsection{Asset Quality}

Asset quality denotes a bank management element that required organisational asset assessment to determine bank measurement level and credit risk size [38]. Following traditional bank functions, loan or financing encompass a major portion of bank assets. In this vein, bank operation and performance optimisation required an in-depth emphasis on revenue-generating bank assets. As high bank financing levels inevitably induced credit risk, strategic credit risk management proved essential for effective and immediate risk control. In this vein, non-performing financing (NPF) and default or impaired financing ratio were typically employed to assess bank credit risk management with the NPF proportion-to-total financing amount $[39,40,41]$.

Perceivably, NPF was impacted by internal and external elements. Research by $[42,43,44]$ demonstrated that macro and microeconomic aspects (GDP and inflation rate) potentially influenced bank NPF. Additionally, internal bank-specific factors (higher capitalisation and inadequate operation) impacted bank NPF $[45,46,47]$. As such, bank management needed to exercise caution in credit policy establishment that might not adversely influence bank economic performance. Low bank asset quality impacted operational and financial performance and a sound economic system. Low-quality bank asset was normally demonstrated in the NPF value. Regarding high NPF values, banks tended to indicate adverse performance that subsequently impacted bank economic performance. Historically, banking industry failures arose from insolvency that was commonly related to substantial NPF accumulation [48]. In this vein, inadequate NPF level reduction potentially resulted in bank failure [49] and inefficiency [50].

Concerning Islamic financial institutions, several studies implied that the Islamic bank asset quality assessed by NPF ratio was better compared to traditional counterparts. Research by [28] in Indonesia, [51] in Pakistan, and [4] in Malaysia demonstrated that Islamic bank asset quality indicated stability compared to traditional counterparts. Observably, banks should develop a means of minimising financing loss reserves and impaired financing and improving past NPF recoveries for high bank asset quality. Globally, specific banking industry research $[5,17,18,39,52,53]$ revealed that asset quality proxied by NPF ratio significantly and adversely influenced bank financial performance. The secondary study data gathered from central bank databases and annual bank reports demonstrated that high NPF amounts resulted in low performance. The finding was justifiable as banks were required for high provision retention to manage defaulted clients. Limited research by [54,55] examined the NPF-Islamic bank financial performance correlation and denoted that NPF-oriented asset quality was implicitly associated with Islamic bank profitability. 
On another note, [56] examined the NPF-profitability correlation among 12 commercial Saudi Arabian banks. The secondary data derived from annual reports between 2009 and 2018 revealed an insignificant and adverse relationship between bank NPF and ROA. Meanwhile, [57] implied a positive NPF-bank profitability correlation.

In light with these observations, the current study formulated the following hypothesis.

H1: There is a negative and significant relationship between the asset quality and the financial performance of Islamic banks in Malaysia.

\subsection{Operational Efficiency}

In [58], operational or cost efficiency denotes organisational proficiency to deter undesired implications and optimise resource utilisation for high-quality customer product and service delivery. Firm operational efficiency relied on specific aspects, such as competent and productive employees, utilised capital [59], digitised intervention [60], and organisational size [61].

Financial institutions are perceived to practise operational efficiency in the presence of high-quality banking service delivery at minimal operational cost $[62,63]$. Particularly, operational efficiency proved attainable when banks employed appropriate resource integrations while restricting operational costs to the favoured level. Additionally, [64,65] revealed operational efficiency to be the key determinant of bank sustainability, efficiency, and productivity. In [66], high bank efficiency originated from income generation and allocation and facilitated productivity and financial advancement. Following [15], operational efficiency was typically proxied by the cost-to-total income ratio. Specifically, operational efficiency ratios were assessed to demonstrate optimal management impacts on cost reduction and revenue generation. High ratios revealed bank inefficiency to minimise operational costs and subsequent business losses.

Most scholars disclosed a correlation between organisational operating efficiency and economic performance. Recent research by [67] in manufacturing [68] in oil and gas sectors investigate the bank operational efficiency-financial performance relationship. The studies utilised financial data gathered from national research databases and organisational annual reports. Resultantly, the sample firm operational efficiency indicated a negative significant association with organisational performance. In other words, low firm operational costs potentially improved economic performance. Several studies also investigated the firm operational efficiency-economic performance regarding market value. Research by [71] involving 244 organisations in India revealed the substantial effect of firm operational efficiency and market value. Notably, [71] corresponded to [72] where a negative and significant operational efficiency-market value correlation was identified among Kenyan organisations between 2008 and 2013.

Regarding banking industries, an operational efficiency ratio implied the bank capacity to optimise operating expense management and profitability. Notably, past research affirmed the operating efficiency-bank profitability correlation $[14,69,70]$. The studies demonstrated that organisations implementing minimal cost operations potentially improved the bank profitability represented by ROA ratio. Contrarily, the investigation of [73] involving the effect of operational efficiency on global hotel sector profitability highlighted that high operational efficiency did not affirm high firm profitability. Likewise, [74] disclosed that operational efficiency reflected minimal effect on bank probability in MENA nations.

This study therefore hypothesized that:

H2: There is negative and significant relationship between operational efficiency and the financial performance of Islamic banks in Malaysia

\section{Methodology}

\subsection{Data}

This study focuses on all Islamic banks in Malaysia. The study employed secondary data that were collected from the respective annual reports of the banks and World Bank website for the period of 10 years (2010-2019). A total of 16 Islamic banks as in Table 1, comprising local and foreign ownership Islamic banks were analysed.

Table 1. List of Islamic bank in Malaysia

\begin{tabular}{ccc}
\hline No. & Particulars & Ownership \\
\hline 1. & Bank Muamalat Malaysia & Local \\
2. & Bank Islam Malaysia & Local \\
3. & MBSB Bank & Local \\
4. & Al-Rajhi Banking \& Investment & Foreign \\
5. & Kuwait Finance House & Foreign \\
6. & Affin Islamic Bank & Local \\
7. & Alliance Islamic Bank & Local \\
8. & AmIslamic Bank & Local \\
9. & CIMB Islamic Bank & Local \\
10. & Public Islamic Bank & Local \\
11. & Hong Leong Islamic Bank & Local \\
12. & Maybank Islamic & Local \\
13. & RHB Islamic Bank & Local \\
14. & HSBC Amanah Malaysia & Foreign \\
15. & OCBC Al-Amin Bank & Foreign \\
16. & Standard Chartered Saadiq & Foreign \\
\hline
\end{tabular}




\subsection{Measurement of Variables}

According to [75] and [76], two measurement elements which can be classified under protection of wealth for Islamic banks are Non-Performing Financing (NPF) and operational efficiency of Islamic banks. These measurements are considered as the measurement of protection of wealth of the banks based on five elements of Maqasid Shariah (objective of Islamic laws) theory; protection of religion, life, mind, lineage and wealth. The studies also highlighted that operational efficiency is an element of measurement for managerial quality while NPF is element of measurement for asset quality of the Islamic banks.
The independent variable of asset quality is represented by NPF to total financing as in the studies of $[18,28,53,54,55]$. The operational efficiency variable is measured by total operating expenses to total revenue as in the studies of $[14,45,41,57,71]$. The dependent variables, ROA is measured by net profit to average total asset, while ROE is measured by net profit to average total equity as in the studies of $[5,11,18,69,77]$. Finally, two financial control variables in this study are size of the banks and leverage as in the studies of $[78,79]$, and two macroeconomic control variables which are gross domestic product and inflation as in the studies of $[42,43,44]$. The operational definition, measurement and sources of the variables are as follows:

Table 2. Measurement of variables

\begin{tabular}{ccc}
\hline Variables & Description & Sources \\
\hline Dependent & Net Profit / Average Total Asset & \\
Return on Asset & Net Profit / Average Total Equity & Annual Reports \\
Return on Equity & & Annual Reports \\
Independent & & \\
Asset Quality & NPF / Total Financing & \\
Operational & Total Operating Expenses / Total Revenue & Annual Reports \\
Efficiency & & \\
Control variables & & Annual Reports \\
Size & The Log of Total Assets & Annual Reports \\
Leverage & Total Liabilities/Total Assets & World Bank \\
Gross Domestic Product & Percentage of GDP per year & World Bank \\
Inflation & Inflation Rates per year &
\end{tabular}

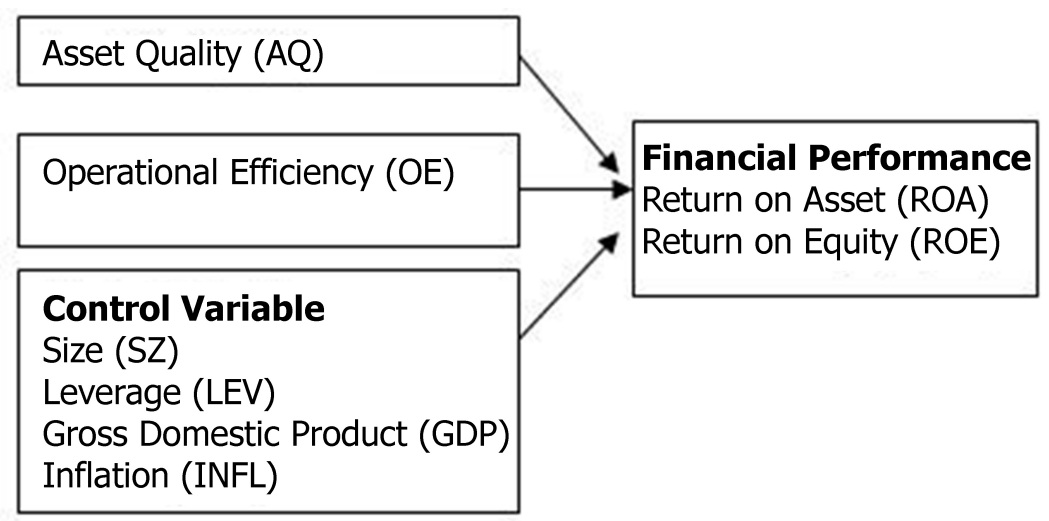

Figure 3. Research Framework 


\subsection{Research Framework and Model}

To establish the relationship of all variables of the study, the framework of the study is conceptualized as in Figure 3.

This study employed multiple regression analyses to test the association between asset quality, operational efficiency and financial performance of the banks. The dependent variable is the financial performance of the banks which is measured by Return on Asset (ROA) and Return on Equity (ROE). While, the independent variables are Asset Quality (AQ) and Operational Efficiency (OE). Also, the study includes bank size (SZ), bank leverage (LEV), Gross Domestic Product (GDP) and inflation rates (INFL) as control variables in the regression models.

The following equations demonstrate the two multiple regression models of the studies:

Model 1: $\mathrm{ROA}_{i t}=\alpha_{0}+\beta_{1} \mathrm{AQ}_{i t+} \beta_{2} \mathrm{OE}_{i t}+\beta_{3} \mathrm{SZ}_{i t}+\beta_{4} \mathrm{LEV}_{i t}+$ $\beta_{5} \mathrm{GDP}_{i t}+\beta_{6} \mathrm{INFL}_{i t}+\varepsilon_{i t}$

Model 2: $\mathrm{ROE}_{i t}=\alpha_{0}+\beta_{1} \mathrm{AQ}_{i t}+\beta_{2} \mathrm{OE}_{i t}+\beta_{3} \mathrm{SZ}_{i t}+\beta_{4} \mathrm{LEV}_{i t}+$ $\beta_{5} \mathrm{GDP}_{i t}+\beta_{6} \mathrm{INFL}_{i t}+\varepsilon_{i t}$

Where,

For each bank $(i)$ and each year $(t)$

ROA $=$ Return on Asset

ROE $=$ Return on Equity

$\mathrm{AQ}=$ Asset Quality

$\mathrm{OE}=$ Operational Efficiency

$\mathrm{SZ}=$ Size

$\mathrm{LEV}=$ Leverage

GDP $=$ Gross Domestic Product

$\mathrm{INFL}=$ Inflation

$\alpha=$ Constant

$\beta=$ Coefficient

$\varepsilon=$ Error

\section{Findings}

In this section, the results of the descriptive statistics of the variables and regression analysis are presented. Several diagnosis tests, such as multicollinearity test, Hausman test, heteroscedasticity test and autocorrelation test were conducted prior to undertaking the regression analysis. The study employed Stata Software Version 14 to analyse the results of the study.

\subsection{Descriptive Analysis}

Table 3 presents the descriptive statistics of the variables in the present study. It presents total the number of observations, mean, median, standard deviation, min, max, skewness and kurtosis values of the variables. The total number of observation (Obs) of the study is 160 . Mean values of ROA, ROE, AQ, OE, SZ, LEV, GDP and INFL are $0.687,9.850,2.380,52.090,4.285,0.912,5.339$ and 2.129 respectively. Meanwhile, the median values of the variables are 0.760 (ROA), 10.125 (ROE), 1.505 (AQ), 47.760 (OE), 4.302 (SZ), 0.922 (LEV), 5.190 (GDP) and 2.095 (INFL). The values of standard deviation of ROA, ROE, AQ, OE, SZ, LEV, GDP and INFL are 0.470, 6.263, $2.803,16.975,0.432,0.039,0.879$ and 0.969 respectively.

In addition, the normality test was conducted by analysing the skewness and kurtosis values of the variables. [80] suggested that the benchmark for skewness value is $+/-3$, while the Kurtosis value is $+/-10$, as recommended by [81]. Table 3 shows the skewness value for ROA is -1.343 and kurtosis is 5.170. The skewness and kurtosis values for ROE are -0.070 and 0.695 respectively. Besides, skewness for $\mathrm{AQ}$ is 4.012 , and the kurtosis value is 21.979 while OE reported skewness and kurtosis values of 0.838 and 0.003 respectively. For the control variables, skewness and kurtosis values of SZ are 0.154 and -0.212 while skewness and kurtosis values for LEV are -1.673 and 2.097 respectively. Moreover, skewness and kurtosis values of GDP are 1.100 and 0.675 while skewness and kurtosis values for INFL are 0.233 and -0.854 respectively. Therefore, the skewness and kurtosis values of all variables in this study are within the acceptable range accept AQ. However, the non-normality of the AQ data is not a big matter, since the sample size is bigger than 100, then non-normality could be relaxed [82].

\subsection{Diagnostic Test}

The diagnostic tests that were employed on the data are explained in this section. Before multivariate regression regression analysis are conducted, several diagnosis tests such as multicollinearity, homoscedasticity and autocorrelation are carried out.

Multicollinearity test is performed to check how independent variables are interrelated in a given model. Correlation matrix, Variance Inflation Factor (VIF) and Tolerance (1/VIF) tests are commonly used to identify multicollinearity in the data findings of the research. Multicollinearity is a problem that arises in the correlation matrix when the correlation values indicate 0.90 and above [83]. From Table 4, all the correlation values are below 0.90 which indicated there is no correlation exists among all variables of the study. 
Table 3. Descriptive statistics

\begin{tabular}{|c|c|c|c|c|c|c|c|c|}
\hline Variable & ROA & ROE & $\mathbf{A Q}$ & $\mathbf{O E}$ & SZ & LEV & GDP & INFL \\
\hline Obs & 160 & 160 & 160 & 160 & 160 & 160 & 160 & 160 \\
\hline Mean & 0.687 & 9.850 & 2.380 & 52.090 & 4.285 & 0.912 & 5.339 & 2.129 \\
\hline Median & 0.760 & 10.125 & 1.505 & 47.760 & 4.302 & 0.922 & 5.190 & 2.095 \\
\hline Min & -1.670 & -9.810 & 0.330 & 21.20 & 3.351 & 0.782 & 4.300 & 0.660 \\
\hline $\operatorname{Max}$ & 2.160 & 30.670 & 12.020 & 100.52 & 5.389 & 0.963 & 7.420 & 3.870 \\
\hline Std. Dev. & 0.470 & 6.263 & 2.830 & 16.975 & 0.432 & 0.039 & 0.879 & 0.969 \\
\hline Skewness & -1.343 & -0.070 & 4.012 & 0.838 & 0.154 & -1.673 & 1.100 & 0.233 \\
\hline Kurtosis & 5.170 & 0.695 & 21.979 & 0.003 & -0.212 & 2.097 & 0.675 & -0.854 \\
\hline & ROA & ROE & AQ & $\mathbf{O E}$ & SZ & LEV & GDP & INFL \\
\hline ROA & 1 & & & & & & & \\
\hline ROE & 0.853 & 1 & & & & & & \\
\hline $\mathrm{AQ}$ & -0.475 & -0.481 & 1 & & & & & \\
\hline $\mathrm{OE}$ & -0.693 & -0.792 & 0.424 & 1 & & & & \\
\hline SZ & 0.456 & 0.635 & -0.315 & -0.583 & 1 & & & \\
\hline LEV & 0.461 & 0.612 & -0.565 & -0.526 & 0.543 & 1 & & \\
\hline GDP & -0.002 & 0.035 & 0.144 & -0.014 & -0.227 & -0.022 & 1 & \\
\hline INFL & -0.050 & -0.042 & 0.039 & 0.058 & -0.096 & -0.003 & 0.039 & 1 \\
\hline
\end{tabular}

Table 5. Variance Inflation Factor Test (VIF)

\begin{tabular}{ccccccc}
\hline Variables & AQ & OE & SZ & LEV & GDP & INFL \\
\hline VIF & 1.81 & 1.59 & 1.91 & 1.99 & 1.25 & 1.11 \\
1/VIF & 0.5515 & 0.6291 & 0.5237 & 0.5020 & 0.7983 & 0.8988
\end{tabular}

Notes: VIF. The average value of VIF is 1.61

The VIF and 1/VIF tests were also conducted in order to detect any multicollinearity in the data set. The values of VIF and $1 / \mathrm{VIF}$ in Table 5 clearly suggest that multicollinearity problem does not exist among the variables of the study. All VIF values are significantly below the threshold of 10 , with an average of 1.61 ; while the $1 / \mathrm{VIF}$ values are above the threshold of 0.10 . Thus, the values of VIF and 1/VIF indicate that the variables of the study are not correlated or redundant [80].

Hausman test is generally performed to choose between fixed effects and random effects models in a research. The null hypothesis underlying the Hausman test is that fixed effects model and random effects model estimators do not differ substantially. Thus, if the null hypothesis is rejected, the conclusion is that random effects model is not appropriate and fixed effects model should be used. If the p-value is significant (i.e., less than 0.05), then fixed-effects should be applied and using random-effects would be biased. However, if the p-value is insignificant, random-effects can be safely used [84]. From Table 6, Hausman test results suggest the random-effects model is more appropriate for Model 1 ( $\mathrm{p}$-value $=0.3597$ ) while fixed-effects model is more appropriate for Model 2 $(p$-value $=0.0009)$

Table 6. Hausman Test

\begin{tabular}{ccc}
\hline Model & $\mathbf{C h i}^{\mathbf{2}}$ & P-value \\
\hline Model 1 & 6.60 & 0.3597 \\
Model 2 & 22.61 & 0.0009 \\
\hline
\end{tabular}

Table 7 shows the Modified Wald Test for the models of the study. The p-values for both models report the significant values at $\mathrm{p}<0.01$. Thus it can be concluded that there is existence of heteroscedasticity in the both models of the study.

Table 7. Modified Wald Test

\begin{tabular}{ccc}
\hline Model & Statistic & P-Value \\
\hline Model 1 & 4998.86 & 0.0000 \\
Model 2 & 588.66 & 0.0000 \\
\hline
\end{tabular}

According to [82] autocorrelation refers to correlation between members of series of observations ordered in time (as in time series data) or space (as in cross sectional data). In detecting the existing of autocorrelation in the models of the study, Wooldridge test are employed. Table 
8 shows the p-values of both models are less than 0.01 . It indicates the existence of autocorrelation the model of study.

Table 8. Wooldridge Test

\begin{tabular}{ccc}
\hline Model & Statistic & P-Value \\
\hline Model 1 & 13.906 & 0.0020 \\
Model 2 & 8.959 & 0.0091 \\
\hline
\end{tabular}

As the above diagnostic tests confirmed that the presence of heteroscedasticity and autocorrelation problems in both models, therefore, the study corrected the issues by employing cluster-robust-VCE estimator in regression analysis as recommended by [85] in order to control the heteroscedasticity and autocorrelation.

\subsection{Multiple Regression Analysis}

Model 1: Regression of Asset Quality and Operational Efficiency on Return on Asset

Random-effect regression model was conducted to test the effect of AQ and OE on the ROA of the Islamic banks. The results of the analysis are shown in the Table 9. F-value of the regression shows the significant value at the $p<0.01$ level. Meanwhile, the adjusted $\mathrm{R}^{2}$ of the results is 0.5053 , which describes that 50.53 per cent of the independent variables describes the total variance of ROA of the bank.

Table 9. ROA Regression Model

\begin{tabular}{ccccc}
\hline & \multicolumn{4}{c}{ Model 1 } \\
\cline { 2 - 5 } Variable & Coef. & $\begin{array}{c}\text { Robust } \\
\text { Std. Err. }\end{array}$ & t & Prob \\
\hline AQ & -0.0354 & 0.0061 & -5.71 & $0.000^{*}$ \\
OE & -0.0191 & 0.0038 & -4.98 & $0.000^{*}$ \\
SZ & -0.0252 & 0.1085 & -0.23 & 0.816 \\
LEV & -0.8008 & 0.6518 & -1.23 & 0.219 \\
GDP & 0.0083 & 0.0414 & 0.20 & 0.841 \\
INFL & -0.0046 & 0.0269 & -0.17 & 0.863 \\
C & 2.5688 & 0.7469 & 3.44 & 0.001 \\
R & \multicolumn{5}{c}{0.7096} \\
Adj. $\mathrm{R}^{2}$ & \multicolumn{5}{c}{0.5053} \\
F-Value & 0.0000 \\
Obs & \multicolumn{5}{c}{160} \\
& Notes: Significant level denoted as *1\%, \\
\hline
\end{tabular}

The results in Table 9 indicate that there is a negative and significant association between $\mathrm{AQ}$ and ROA, at a $1 \%$ level of significance $(p<0.01)$. Similarly, there is a negative and significant relationship between $\mathrm{OE}$ and ROA, at a $1 \%$ level of significance $(p<0.01)$. For control variables, GDP shows an insignificant positive relationship while SZ, LEV and INFL the result indicates negative association and insignificant.
Model 2: Regression of Asset Quality and Operational Efficiency on Return on Equity

Fixed-effect regression model was conducted to test the effect of AQ and OE on the ROE of the Islamic banks. The results of the analysis are shown in the Table 10. F-value of the regression shows the significant value at the $\mathrm{p}<0.01$ level. Meanwhile, the adjusted $\mathrm{R}^{2}$ of the results is 0.3519 , which describes that 35.19 percent of the independent variables describes the total variance of $\mathrm{ROE}$ of the bank.

Table 10. ROE Regression Model

\begin{tabular}{ccccc}
\hline \multirow{2}{*}{ Variable } & Coef. & $\begin{array}{c}\text { Robust } \\
\text { Std. Err. }\end{array}$ & t & Prob \\
\cline { 2 - 5 } & -0.2769 & 0.1117 & -2.48 & $0.025^{* *}$ \\
AQ & -0.2565 & 0.0433 & -5.93 & $0.000^{*}$ \\
OE & -4.0401 & 2.0895 & -1.93 & 0.072 \\
SZ & 13.9137 & 16.3979 & 0.85 & 0.409 \\
LEV & -0.0837 & 0.3069 & -0.27 & 0.789 \\
GDP & -0.1273 & 0.2143 & -0.59 & 0.561 \\
INFL & 29.2236 & 12.6132 & 2.32 & 0.035 \\
C & \multicolumn{5}{c}{0.3763} \\
R ${ }^{2}$ & 0.3519 \\
Adj. R ${ }^{2}$ & \multicolumn{5}{c}{0.0002} \\
F-Value & \multicolumn{5}{c}{160} \\
Obs & Notes: Significant level denoted as *1\%,**10\% \\
\hline \multicolumn{5}{c}{}
\end{tabular}

The results in Table 10 indicate that there is a negative and significant association between AQ and ROE, at a $10 \%$ level of significance $(p<0.1)$. Meanwhile, the regression results of ROE model show a negative and significant relationship between $\mathrm{OE}$ and $\mathrm{ROE}$, at a $1 \%$ level of significance $(p<0.01)$. For the control variable $S Z$, GDP and INFL, the result indicates negative association and insignificant. While, for the control variable LEV, the result indicates positive association and insignificant.

\section{Discussion}

The results of the study provide the evidence on how asset quality and operational efficiency influence the financial performance of the Islamic banks in Malaysia. The results of the study reveal that there is a significant effect of asset quality and operational efficiency on financial performance measured by ROA and ROE.

Based on the above findings, the hypotheses of the study can be summarised as below:

Table 11. Summary of the findings

\begin{tabular}{ccc}
\hline & \multicolumn{2}{c}{ Financial Performance } \\
Hyphoteses & ROA & ROE \\
\hline H1 & Supported & Supported \\
H2 & Supported & Supported \\
\hline
\end{tabular}


The regression results of the assets quality on the financial performance proxied by ROA and ROE are in line with the findings of previous studies of $[18,39,52,54,55]$, which found a significant negative effects of asset quality on financial performance of the organisations. It indicated that asset quality measured by NPF ratio negatively impact the ROA and ROE of the banks. In other words, by decreasing the NPF ratio value it could increase the profitability of the Islamic banks. As stated by [38] improper management of asset quality will increase NPF and may eventually lead to the financial distress of the banks. However, the results of the study are different from the study of [56] which found that asset quality has no effect on the financial performance of the banks.

Meanwhile, the regression results of operational efficiency on the ROA and ROE are consistent with the findings of $[57,68,69,70]$ that found a significant negative effects of the operational efficiency on profitability such as ROA and ROE of the firms. Thus, high operational efficiency by reducing cost in Islamic banks would lead to enhance the profitability of the banks. Conversely, the results of the study are contradicting to the findings of [74] which stated that operational efficiency has insignificant impact on the performance of the firms.

As agency theory posits that the company owner (principal) entrust the management of the firms (agent) to increase the wealth of the principal by increasing the value of the firms. Thus, management of the banks should take great efforts in managing asset quality as well as increasing operational efficiency because the important roles of the asset quality and operational efficiency as a reflection to the level of competitive financial performance of the Islamic banks

\section{Conclusions}

The objective of is study is to examine the effect of asset quality and operational efficiency on financial performance of the Islamic banks. The study uses ROA and ROE measures for financial performance and includes four control variables which are size, leverage, gross domestic product and inflation. The study investigates a sample of 16 Malaysian Islamic banks over a 10-year period from 2010 to 2019. Based on the results of the study, it can be concluded that asset quality and operational efficiency have a significant effect on the. Results of this study are expected to serve as an alarm to the management of the banks in managing their asset quality and operational efficiency to enhance financial performance of the banks in order to have the competitive advantage to compete with other players as well as to retain their valuable customers.

In terms of the limitation of the study, the data for the study is secondary data which was derived from the annual reports of the 16 Islamic banks available from their websites for the period of ten years (from 2010 until 2019) only. Instead of focusing on Islamic banks, future research may consider other types of banks and other Islamic regions. Those organisations may have a different perspective and variance in asset quality, operational efficiency and financial performance.

\section{Acknowledgements}

The authors would like to thank the individuals who generously helped to shape this final draft by incorporating useful comments and discussion on earlier draft.

\section{REFERENCES}

[1] Albaity, M., Mallek, R. S. and Noman, A. H. M. 'Competition and bank stability in the MENA region: The moderating effect of Islamic versus conventional banks', Emerging Markets Review, vol. 38, pp. 310-325, 2019.

[2] Alqahtani, F. and Mayes, D. G. 'Financial stability of Islamic banking and the global financial crisis: Evidence from the Gulf Cooperation Council', Economic Systems, vol. 42, pp. 346-360, 2018.

[3] Islamic Financial Services Board. 'Islamic Financial Services Industry Stabilty Report 2020', available at https://www.ifsb.org (accessed 1 January 2021).

[4] Isaev, M. and Masih, M. 'Macroeconomic and bank-specific determinants of different categories of non-performing financing in Islamic banks: Evidence from Malaysia, MPRA Paper 79719, University Library of Munich, Germany. 2017.

[5] Salike, N. and Ao, B. 'Determinants of bank's profitability: Role of poor asset quality in Asia', China Finance Review International, vol. 8, no. 2, pp. 216-231, 2018.

[6] Ismail, F., Abd Majid, M. S. and Ab Rahim, R. 'Efficiency of Islamic and conventional banks in Malaysia', Journal of Financial Reporting and Accounting, vol. 11, no. 1, pp. 92-107, 2013.

[7] Jaafar, M. and Manarvi, I. 'Performance comparison of Islamic and Conventional banks in Pakistan', Global Journal of Management and Business Research, vol. 11, no.1, pp.60-66, 2011

[8] Dusuki, A. W. and Bouheraoua, S. 'The framework of maqās.id al-sharī'ah and its implication for Islamic finance,' Islam and Civilization Renewal Journal, vol. 2, no. 2, pp. 316-336, 2011.

[9] Antony, J. P., and Bhattacharyya, S. 'Measuring organizational performance and organizational excellence of SMEs Part 2: An empirical study on SMEs in India,' Measuring Business Excellence, vol.14, no. 3, pp. 42-52. 2010. 
[10] Ong, C. H. and Chen, P. Y. 'The effects of IT: From performance to value', Industrial Management \& Data Systems, vol. 114, no.1, pp. 70-85, 2014.

[11] Mallin, C., Farag, H. and Ow-Yong, K. 'Corporate social responsibility and financial performance in Islamic banks', Journal of Economic Behavior and Organization, vol. 103, pp. 21-38, 2014.

[12] El Mousaid, F. and Boutti, R. 'Relationship between corporate social responsibility and financial performance in Islamic banking', Research Journal of Finance and Accounting, vol. 3, no.10, pp. 93-103, 2012.

[13] Arshad, R., Othman, S. and Othman, R. 'Islamic corporate social responsibility, corporate reputation and performance', International Journal of Social, Behavioral, Educational, Economic, Business and Industrial Engineering, vol. 6, no. 4, pp. 643-647, 2012.

[14] Sressha, C. H. 'A Study on the effect of bank size and operational efficiency on performance of banks', International Journal of Research, vol.1, Iss.6, pp. 274-286, 2014.

[15] Shah, S. Q. and Jan, R. 'Analysis of financial performance of private banks in Pakistan', Procedia - Social and Behavioral Sciences, vol. 109, pp.1021-1025, 2014.

[16] Hafez, H. 'Corporate social responsibility and financial performance: An Empirical study on Egyptian banks', Corporate Ownership \& Control, vol. 12, no. 2, pp. 105-127, 2015.

[17] Etale, L. M., Ayunku,. P. E. and Etale, E. L. M. 'The impact of non-performing loans and bank performance in Nigeria', International Journal of Humanities and Social Science Invention, vol. 5, Iss.4, pp. 1-5, 2016.

[18] Ozurumba, B. A. 'Impact of non-performing loans on the performance of selected commercial banks in Nigeria', Research Journal of Finance and Accounting, vol.7, no.16, pp. 95-109, 2016.

[19] Menne, F. Winata, L. and Hossain, M. 'The Influence of CSR practices on financial performance: Evidence from Islamic financial institutions in Indonesia', Jurnal of Modern Accounting and Auditing, vol. 12, no. 2, pp. 77-90, 2016.

[20] Nizar al-Malkawi, H.A. and Pillai, R. 'Analyzing financial performance by integrating conventional governance mechanisms into the GCC Islamic banking framework', Managerial Finance, vol. 44, no. 5, pp. 604-623, 2018.

[21] Sufian, F., and Kamarudin, F. 'Determinants of revenue efficiency of Islamic banks: Empirical evidence from the Southeast Asian countries', International Journal of Islamic and Middle Eastern Finance and Management, vol. 8, no. 1, pp. 36-63, 2015.

[22] Hadriche, M. 'Banks performance determinants: Comparative analysis between conventional and Islamic banks from GCC countries', International Journal of Economics and Finance, vol. 7, no.9, pp. 169-177, 2015.

[23] Lee, S. P., and Isa, M. 'Determinants of bank margins in a dual banking system', Managerial Finance, vol. 43, no. 6, pp. 630-645, 2017.

[24] Chowdhury, M. A. F. and Mohd Rasid, M. E. S
'Determinants of performance of Islamic banks in GCC countries: Dynamic GMM approach', Advances in Islamic Finance, Marketing, and Management, pp. 49-80, 2017.

[25] Wasiuzzaman, S. and Ahmad Tarmizi, H. 'Profitability of Islamic banks in Malaysia: An empirical analysis', Journal of Islamic Economics, Banking and Finance, vol. 6, no. 4, pp. 53-68, 2010.

[26] Abdul Majid, M. J. H. and Kassim, S. H. 'Assessing the contribution of Islamic finance to economic empirical evidence from Malaysia', Journal of Islamic Accounting and Business Research, vol. 6, no. 2, pp. 292-310, 2015.

[27] Gani, I. M. and Bahari, Z. 'Islamic banking's contribution to the Malaysian real economy', ISRA International Journal of Islamic Finance., 2021.

[28] Prima Sakti, M. R. P. and Mohamad, A. 'Efficiency, stability and asset quality of Islamic vis-à-vis conventional banks; Evidence from Indonesia', Journal of Islamic Accounting and Business Research, vol. 9, no. 3, pp. 378-400. 2018.

[29] Khan, I., Khan, M. and Tahir, M. ' Performance comparison of Islamic and conventional banks: empirical evidence from Pakistan', International Journal of Islamic and Middle Eastern Finance and Management, vol. 10, no.3, pp. 419-433, 2017.

[30] Masruki, R., Ibrahim, N., Osman, E. and Abdul Wahab, H. 'Financial performance of Malaysian founder Islamic banks versus conventional banks', Journal of Business and Policy Research, vol. 6, no. 2, pp. 67-79, 2011.

[31] Wasiuzzaman, S. and Gunasegavan, U. N. 'Comparative study of the performance of Islamic and conventional banks: The case of Malaysia', Humanomics, vol. 29, no. 1, pp. 4360, 2013.

[32] Sulaiman, A. A., Mohamad, M. T., and Hashim, S. A. 'Islamic versus conventional banking: Characteristics and stability analysis of the Malaysian banking sector', New Developments in Islamic Economics, pp. 119-214, 2018.

[33] Johnes, J., Izzeldin, M. and Pappas, V. 'A comparison of performance of Islamic and conventional banks 2004-2009', Journal of Economic Behavior \& Organization, vol. 103, pp. 93-107, 2014.

[34] Mokni, R. B. M. and Rachdi, H. 'Assessing the bank profitability in the MENA region A comparative analysis between conventional and Islamic bank', International Journal of Islamic and Middle Eastern Finance and Management, vol. 7, no. 3, pp. 305-332, 2014.

[35] Islamic Financial Services Board 'Islamic Financial Services Industry Stabilty Report 2019', available at https://www.ifsb.org (accessed 7 January 2021)

[36] Iqbal, Z. and Mirakhor A. 'Introduction to Islamic finance: Theory and practice', John Wiley and Sons (Asia), Singapore, 2007.

[37] Ravichandran, T., Liu, Y., Han, S. and Hasan, I. 'Diversification and firm performance: Exploring the moderating effects of information technology spending,' Journal of Management Information Systems, vol. 25, no. 4, pp. 205-240, 2009.

[38] Adeolu, A. M. 'Asset quality and bank performance: a study 
of commercial banks in Nigeria,' Research Journal of Finance and Accounting, vol.5, no.18, pp. 39-44. 2014.

[39] Bhattarai, Y. R. 'Effect of Non-Performing Loan on the Profitability of Commercial Banks in Nepal', Prestige International Journal of Management and Research, vol. 10, no.2, pp. 1-10, 2017.

[40] Ghenimi, A., Chaibi, H. and Omri, M. A. B. 'Liquidity risk determinants: Islamic vs conventional banks,' International Journal of Law and Management, vol. 63, no.1, pp. 65-95, 2021.

[41] Lotto, J. 'The empirical analysis of the impact of bank capital regulations on operating efficiency,' International Journal of Financial Studies, vol. 6, no. 34, pp. 1-11, 2018.

[42] Mpofu, T. R. and Nikolaidou, E. 'Determinants of credit risk in the banking system in Sub-Saharan Africa,' Review of Development Finance, vol. 8, pp. 141-153, 2018.

[43] Umar, M. and Sun, G, 'Determinants of non-performing loans in Chinese banks;' Journal of Asia Business Studies, vol. 12, no. 3, pp. 273-289, 2018.

[44] Steahr, K. and Uuskula, L. 'Macroeconomic and macro-financial factors as leading indicators of non-performing loans; Evidence from the EU countries,' Journal of Economic Studies, vol. 48, no. 3, pp. 720-740, 2020.

[45] Abid, L., Ouertani, M. N. and Ghorbel, S. Z. 'Macroeconomic and bank-specific determinants of household's non-performing loans in Tunisia: A dynamic panel data,' Procedia Economics and Finance, vol. 13, pp. 58-68, 2014.

[46] Kumar, R. R., Stauvermann, P. J., Patel, A. and Prasad, S. S. 'Determinants of non-performing loans in banking sector in small developing island states; A study of Fiji,' Accounting Research Journal, vol. 31, no. 2, pp. 192-213, 2018.

[47] Lee, Y. Y., Yahya, M. H., Habibullah, M. S. and Mohd Ashhari, Z. 'Non-performing loans in European Union: Country governance dimensions,' Journal of Financial Economic Policy, vol. 12, no. 2, pp. 209-226, 2020.

[48] Campbell, A. 'Bank insolvency and the problem of non-performing loan, Journal of Banking Regulation, vol. 9, no.1, pp. 25-45, 2007.

[49] Samad, A. 'Credit risk determinants of bank failure: Evidence from us bank failure,' International Business Research, vol. 5, no. 9; pp. 10-15, 2012.

[50] Saleh, A.S., Moradi-Motlagh, A. and Zeitun, R. 'What are the drivers of inefficiency in the Gulf cooperation council banking industry? A comparison between conventional and Islamic banks,' Pacific-Basin Finance Journal, vol. 60, pp. $1-12,2020$.

[51] Akram, H. and Rahman K. U. 'Credit risk management; A comparative study of Islamic banks and conventional banks in Pakistan,' ISRA International Journal of Islamic Finance, vol. 10, no. 2, pp. 185-205, 2018.

[52] Akter, R and Roy, J. K. 'The impacts of non-performing loan on profitability: An empirical study on banking sector of Dhaka stock exchange,' International Journal of Economics and Finance, vol. 9, no. 3, pp. 126-132, 2017.
[53] Kingu, P. S., Macha, S. and Gwahula, R. 'Impact of non-performing loans on bank's profitability: Empirical evidence from commercial banks in Tanzania,' International Journal of Scientific Research and Management, vol. 6, no. 3, pp. 71-78, 2018.

[54] Samail, N. A., Zaidi, N. S., Mohamed, A. S. and Kamaruzaman, M. N. 'Determinants of financial performance of Islamic banking in Malaysia,' International Journal of Academic Research in Accounting, Finance and Management Sciences, vol. 8, no.4, pp. 21-29, 2018.

[55] Sanwari, S. R. and Zakaria, R H. 'The performance of islamic banks and macroeconomic conditions' ISRA International Journal of Islamic Finance, vol. 5, Iss. 2, pp. 83-98, 2013.

[56] Alshebmi, A. S., Mohammad Adam, M. H., Mustafa, A. M. A., Thomran, M. and Fathelbab, E. A. 'Assessing the non-performing loans and their effect on banks profitability: Empirical evidence from the Saudi Arabia banking sector,' International Journal of Innovation, Creativity and Change, Vol. 11, Iss. 8, pp. 69-90, 2020.

[57] Buchory, H. A. 'Banking profitability: How does the credit risk and operational efficiency effect?' Journal of Business and Management Sciences, vol. 3, no. 4, pp. 118-123, 2015.

[58] Kalluru, S. R. \& Bhat S. K. 'Determinants of cost efficiency of commercial banks in India,' The IUP Journal of Bank Management, vol. 8, no. 2, pp. 32-50, 2009.

[59] Gupta, K. and Raman, T. V. 'Intellectual capital: a determinant of firms' operational efficiency,' South Asian Journal of Business Studies, vol. 10, no. 1, pp. 49-69, 2021.

[60] Mohapatra, S. and Mohanty, S. 'Improving operational efficiency in utility sector through technology intervention,' International Journal Enterprise Network Management, vol. 8, no. 4, pp. 291-326, 2017.

[61] Deb, A. 'Operational efficiency and size of commercial banks: A study of the Indian banking sector,' International Journal of Research in Humanities, Arts and Literature, vol. 7, Iss. 6, pp. 11-20, 2019.

[62] Allen, L. and Rai, A. 'Operational efficiency in banking: An intemational comparison,' Journal of Banking \& Finance, vol. 20, pp.655-672, 1996.

[63] Jimborean, R. and Brack, E. 'The cost-efficiency of French banks,' MPRA Paper 23471, University Library of Munich, Germany, 2010.

[64] Ghosh, S. and Sanyal, B. 'Determinants of operating efficiency of commercial banks in India: Insights from panel regression model,' Das, R.C. (Ed.) The Impacts of Monetary Policy in the 21st Century: Perspectives from Emerging Economies, Emerald Publishing Limited, Bingley, pp. 253-263. 2019.

[65] Ayayi, G. A. and Sene, M. 'What drives microfinance institutions financial sustainability, The Journal of Developing Areas, vol. 44, pp. 303-324, 2010.

[66] Beck, T., Demirgüç-Kunt, A. and Levine, R. 'A New Database on Financial Development and Structur', World Bank Economic Review, vol. 14, pp. 597-605, 2000.

[67] Lee, J., Kwon, H. B. and Pati, N. 'Exploring the relative impact of R\&D and operational efficiency on performance: 
A sequential regression-neural network approach,' Expert Systems with Applications, vol. 137, pp. 420-431, 2019.

[68] Azad, Raza, and Zaidi, empirical relationship between operational efficiency and profitability: Evidence from Pakistan exploration sector,' Journal of Accounting, Business and Finance Research, Vol. 2, No. 1, pp. 7-11, 2018.

[69] Christaria, F. and Kurnia, R. 'The impact of financial ratios, operational efficiency and non-performing loan towards commercial bank profitability,'Accounting and Finance Review, vol. 1, no. 1, pp, 43-50, 2016.

[70] Adam, M., Safitri, R. Wahyudi, T. 'Effect of company size, liquidity and operational efficiency on bank profitability with problem credit risk as a moderating variable at commercial banks that are listed on the Indonesia Stock Exchange, Jurnal Perspektif Pembiayaan dan Pembangunan Daerah, vol. 6. no. 3, pp. 331-344, 2018.

[71] Gill, A., Singh, M. Mathur, N. and Mand, H. 'The impact of operational efficiency on the future performance of Indian manufacturing firms,' International Journal of Economics and Finance, vol. 6, no. 10, pp. 259-269, 2014.

[72] Njagi, J. N., Aduda, J., Kisaka, S. E. and Iraya, C. 'Capital structure, firm efficiency and firm value: The case of listed non-financial firms in Kenya,' European Journal of Business and Management, vol. 9, no. 22, pp. 71-81, 2017.

[73] Chiu, Y. H. and Huang, C. W. 'Evaluating the optimal occupancy rate, operational efficiency, and profitability efficiency of Taiwan's international tourist hotels,' The Service Industries Journal, vol. 31, no. 13, pp. 2145-2162, 2011.

[74] Olson, B. and Zoubi, T. A. 'Efficiency and bank profitability in MENA countries,' Emerging Markets Review, vol.12, pp. 94-110, 2011.

[75] Noordin, K and Hudaefi, F. A. 'Harmonizing and Constructing an integrated Maqasid Al-Sharī'ah index for measuring the performance of Islamic banks,' ISRA
International Journal of Islamic Finance, vol. 11, no. 2, pp. 282-302, 2019.

[76] Asutay, M. and Harningtyas, A. F. 'Developing Maqasid al-Shari'ah Index to evaluate social performance of islamic banks: A conceptual and empirical attempt,' International Journal of Islamic Economics and Finance Study, vol.1, no. 1, pp. 5-64, 2015.

[77] Dey, S. K. and Sharma, D. 'Nexus between corporate governance and financial performance: Corroboration from Indian banks,' Universal Journal of Accounting and Finance, vol. 8 , no. 4, pp. 140-147, 2020. DOI: 10.13189/ujaf.2020.080406.

[78] Devie, D., Liman, L. P., Tarigan, J. and Jie, F. 'Corporate social responsibility, financial performance and risk in indonesian natural resources industry, Social Responsibility Journal, vol. 16, no. 1, pp. 73-90, 2018.

[79] Buallay, A. 'Is sustainability reporting (ESG) associated with performance? Evidence from the European banking sector,' Management of Environmental Quality: An International Journal, vol. 30, no. 1, pp. 98-115, 2018.

[80] Hair, J. F., Black, W. C., Babin, B. J. \& Anderson, R. E. 'Multivariate data analysis' Upper Saddle River, New Jersey: Prentice Hall, Upper Saddle River, New Jersey, 2010.

[81] Kline, R. B. 'Principles and practice of structural equation modeling,' Guilford press, New York, 2011

[82] Gujarati, D. N., and Porter, D. C. 'Essentials of Econometrics,' Mc GrawHill, 2010.

[83] Pallant, J. 'SPSS Survival Manual. (4 thEd.),' Open University Press, McGrawHill: Berkshire, England, 2010.

[84] Wooldridge, J. M. 'Econometric Analysis of Cross Section and Panel Data,' The MIT Press, 2010.

[85] Hoechle, D. 'Robust standard errors for panel regressions with cross-sectional dependence.' Stata Journal, vol. 7, no.3, pp. 281-312. 2007. 